Karolina KurYŚ-SZYNCEL

ORCID 0000-0002-1934-6090

Uniwersytet im. Adama Mickiewicza

$w$ Poznaniu

\title{
EPIZODY \\ WSPÓLNEGO ZAANGAŻOWANIA BIOGRAFICZNEGO JAKO ŹRÓDŁO MĄDROŚCI ŻYCIOWEJ
}

AвSTRACT. Kuryś-Szyncel Karolina, Epizody wspólnego zaangażowania biograficznego jako źródto mądrości życiowej [Joint Biographical Involvement Episodes as a Source of Wisdom]. Studia Edukacyjne nr 55, 2019, Poznań 2019, pp. 109-123. Adam Mickiewicz University Press. ISSN 1233-6688. DOI: 10.14746/ se.2019.55.7

The aim of the article is to introduce the author's category of joint biographical involvement episodes (EWZB) into the space of educational discourse, especially in relation to adult education (including academic teacher training). The proposed EWZB category derives from the work of Rudolf Schaffer on episodes of joint engagement and is enriched with knowledge on biographical learning. The author notes that one of the volitional goals of adult learning is the desire to acquire wisdom, understood as an aspect of personality development in adulthood, and the basis for building it is learning based on the co-experience of both one's own and Others' biographies.

Key words: joint biographical involvement episodes, wisdom, biographical learning

\section{Wprowadzenie}

„Gdy ktoś oznajmia, że szuka nauczyciela gry w tenisa albo języka spotyka się z aplauzem. Jednakże mało kto zaryzykowałby wyznanie, że szuka nauczyciela mądrości"1.

Współczesne szybkie tempo życia i nieustanne zmiany konfiguracji wymagań oraz oczekiwań społecznych sprawiają, że namysł, refleksja, kontemplacja i wsłuchiwanie się w swoje potrzeby są tymi stanami, które na

${ }^{1}$ Z. Pietrasiński, Mądrość, czyli świetne wyposażenie umystu, Warszawa 2001, s. 16. 
pierwszy rzut oka stanowią przeszkodę na drodze do sukcesu zarówno w sferze prywatnej, jak i zawodowej. Jednak, jeśli przyjrzymy się dokładniej, to szczególnie wśród osób z pokolenia $X^{2}$, które w Polsce stanowi obecnie najliczniejszą grupę pracowników (tzw. starszych pracowników) zarówno w sektorze prywatnych przedsiębiorstw, jak i instytucji publicznych ${ }^{3}$, szczególnego znaczenia zaczynają nabierać nawyki wywodzące się z praktyki mindfulness ${ }^{4}$. Wyposażenie siebie samego $\mathrm{w}$ umiejętne korzystanie $\mathrm{z}$ technik uważności, medytacji i skupienia na byciu tu i teraz ma walory wzmacniające nasze poczucie sprawstwa, kontroli oraz adekwatności dokonywanych wyborów, ale wydaje się, że nieocenioną (bezcenną) kompetencją życiową, która zapewni stabilność struktury osobowości i w pewnym sensie ochroni nas przed często zgubnym wpływem (działaniem) czynników nagłych i niespodziewanych (np. zmiana pracy, przeprowadzka, choroba, rozpad bliskich związków) jest tak zwana mądrość życiowa, rozumiana jako swoista synteza wielu właściwości psychicznych (poznawczych, afektywnych i behawioralnych). Aktywny podmiot dążący do mądrości życiowej stawia problemy poznawcze, dokonuje wyborów życiowych (np. w obszarze wartości) i wyniki swoich dociekań stara się realizować (sprawdzać) w codziennych działaniach ${ }^{5}$. Nabywanie owej mądrości jest zatem celem wszelkich działań o charakterze edukacyjnym, w szczególności kierowanych do osób dorosłych. Zadaniem edukatora jest przede wszystkim prowokowanie swoich uczniów do podejmowania wyzwań zarówno poznawczych, jak i emocjonalnych, a tym samym do projektowania twórczej (autorskiej) ścieżki osobistego rozwoju i kierowania własnym życiem ${ }^{6}$. W niniejszym artykule zostaje postawione pytanie: czy „epizody wspólnego zaangażowania"7 w odniesieniu do edukacji dorosłych mogą przyjąć formę "biograficznych" oraz na ile "zaangażowanie biograficzne" uczestników wzajemnego uczenia się stanowi dla nich źródło mądrości życiowej?

\footnotetext{
${ }^{2}$ Pokolenie X (zwane także pokoleniem PRL lub pokoleniem nic na serio) to generacja osób urodzonych w latach 1965-1979.

${ }^{3}$ https://www.karierawfinansach.pl/baza-wiedzy/slownik-pojec/pokolenie-x-co-oznacza-pojecie-pokolenie-x [data dostępu: 25.11.2019]; https://blog.absolvent.pl/zmiany-rynku-pracy-pokolenie-podyktuje-warunki/ (data dostępu: 25.11.2019).

${ }^{4}$ Mindfulness, czyli uważność najczęściej definiowana jest jako nieoceniająca świadomość tego, czego się doświadcza w bieżącym momencie; uważność odnosi się zarówno do myśli, uczuć (afektów), jak i zachowań. Patrz np. J. Kabat-Zinn, Mindfulness-based interventions in context: past, present and future, Clinical Psychology: Science and Practice, 2003, 10, s. 144-156.

${ }^{5}$ Z. Pietrasiński, Mądrość, czyli świetne wyposażenie umystu.

${ }^{6}$ Z. Pietrasiński, Rozwój człowieka dorosłego, Warszawa 1990, s. 138-141.

${ }^{7}$ H.R. Schaffer, Epizody wspólnego zaangażowania jako kontekst rozwoju poznawczego, [w:] Dziecko w świecie ludzi i przedmiotów, red. A. Brzezińska, G. Lutomski, Poznań 1994, s. 150-188.
} 


\section{Mądrość życiowa - wybrane propozycje koncepcyjne}

Mądrość życiową najczęściej rozpatruje się z dwóch perspektyw: koncepcji intuicyjnych i koncepcji wyartykułowanych/systematycznych. W pierwszym ujęciu posługujemy się wiedzą potoczną, pochodzącą z codziennego obcowania z osobami powszechnie uznawanymi za mądre. Mądry zatem to ten, kto rozumie istotę/sens życia, wie kiedy i jak udzielać rad, jest świadomy dynamiki/polifonii życia, jest „ludzki”. Z kolei, w ujęciu „naukowym” mądrość życiowa może być rozumiana jak mądrość w odniesieniu do siebie/ do „ja" $\mathrm{j}^{\prime 8}$ oraz cecha osobista ${ }^{9}$, czy własność osoby „autora siebie” ${ }^{\prime 10}$. W wielu opracowaniach i pracach badawczych mądrość (także mądrość życiowa) rozpatrywana jest jako atrybut poznawczy, pewien specjalny rodzaj wiedzy odnoszącej się do życia. Można tu wskazać na przykład Berliński Paradygmat Mądrości ${ }^{11}$, w którym mądrość to system ekspercki/znawstwo w dziedzinie podstawowej pragmatyki życiowej. Z kolei Zbigniew Pietrasiński, poświęcając mądrości życiowej kilka znaczących publikacji, traktuje ją jako wiedzę proceduralną, używaną w sposób twórczy do rozwiązywania problemów życiowych ${ }^{12}$. Natomiast, w koncepcjach neopiagetowskich mądrość to efekt myślenia postformalnego ${ }^{13}$. Ciekawą realizacją postrzegania mądrości przez pryzmat psychologii biegu życia (life span psychology) jest koncepcja Caroline Bassett, w myśl której

mądrość odzwierciedla wyższy poziom rozwoju osobowości i wyłania się w efekcie dynamicznej integracji czterech podstawowych komponentów: wnikliwości, szacun$\mathrm{ku}$, zaangażowania i transformacji ${ }^{14}$.

${ }^{8}$ U.M. Staudinger, J. Dörner, C. Mickler, Wisdom and personality, [w:] A handbook of wisdom. Psychological perspective, red. R.J. Sternberg, J. Jordan, Cambrige 2005, s. 191-219.

9 Np. D.P. McAdams, E. de St. Aubin, R.L. Logan, Generativity among young, midlife, and older adults, Psychology and Aging, 1993, 8, s. 221-230.

${ }^{10}$ K. Obuchowski, Człowiek intencjonalny, czyli o tym jak być soba, Poznań 2000; tenże, The subjects' revolution, WSHE, Łódź 2005; W. Ożarowski, Ustalenie przydatności Popperowskiej zasady falsyfikacji do oceny koncepcji osobowości autorskiej, Horyzonty Psychologii, 2011, I (1), s. 101-126; A. Błachnio, Autor siebie w trzeciej fali cywilizacyjnej, Bydgoszcz 2006; taże, Człowiek autorski w erze globalizacji, Bydgoszcz 2011.

${ }^{11}$ P.B. Baltes, J. Gluck, U. Kunzmann, Mądrość. Jej struktura i funkcja w kierowaniu pomyślnym rozwojem w okresie catego życia, [w:] Psychologia pozytywna. Nauka o szczęściu, zdrowiu, sile i cnotach cztowieka, red. J. Czapiński, Warszawa 2004, s. 117-146.

${ }_{12}$ Z. Pietrasiński, Mądrość, czyli świetne wyposażenie umystu; tenże, Ekspansja pięknych umysłów. Nowy renesans i ożywcza autokreacja, Warszawa 2008.

${ }^{13}$ G. Laubovie-Vief, Wisdom as integrated throught: historical and developmental perspective, [w:] Wisdom: It's nature, origins, and development, red. R.J. Sternberg, New York 1990, s. 52-183.

${ }_{14}$ C. Bassett, Emergent wisdom: Living a life in widening circles, ReVison, 2005, 27, s. 3-17, cyt. za: S. Steuden, P. Brudek, Ł. Florczyk, Mądrość jako efekt pozytywnego starzenia się. Perspektywa psychologiczna, Forum Teologiczne, 2016, XVII, s. 80. 
Wspólną cechę wszystkich podejść stanowi to, jak pisze Agnieszka Kozerska, „że mądrość jest kojarzona z dobrym życiem, z dobrostanem, szczęściem człowieka"15. Mądrość to także atrybut starości, jest postrzegana jako osiągnięcie rozwojowe ostatniej fazy rozwoju człowieka i efekt pozytywnego starzenia się ${ }^{16}$ oraz bardzo często stanowi bazę do tak zwanego międzypokoleniowego mentoringu ${ }^{17}$.

Mądrość życiowa jest czymś więcej niż „zwykłą” mądrością. Odnosi się bowiem nie tylko do specyfiki funkcjonowania poznawczego (choć system ekspercki, jak wskazują opisane poniżej badania, wydaje się tu niezbędny), ale także do specyficznej postawy życiowej, realizującej się zarówno w głoszonych poglądach jak i decyzjach (wyborach) i będących ich pochodną zachowaniach (czynach). Mądrość życiowa ujawnia się w konfrontacji z okolicznościami życia, szczególnie w sytuacjach trudnych (często o charakterze konfliktowym ${ }^{18}$ ), sytuacjach nagłych i niespodziewanych, do których człowiek nie mógł się w żaden sposób przygotować (np. choroba, śmierć bliskiej osoby, rozwód) i nie ma gotowych recept czy scenariuszy radzenia sobie $\mathrm{z}$ nimi ${ }^{19}$. Według badań Baltesa,

cnotę mądrości ludzie przypisują takiej osobie, która posiada pogłębioną refleksję nad codziennymi doświadczeniami, potrafi je zrozumieć, wnikając w istotę rzeczy i ujmując ją we właściwym kontekście (a nie w oderwaniu od niego), bierze pod uwagę rozmaite punkty widzenia oraz potrafi trafnie przewidywać konsekwencje różnych działań, a ponadto nie jest skoncentrowana na sobie, lecz jest otwarta na problemy, tolerancyjna i daleka od osądzania innych ${ }^{20}$.

Jednakże, kluczową właściwością okazuje się wiedza ekspercka. Jak wskazują badania prowadzone pod kierunkiem Paula Baltesa „trzeba dobrze wiedzieć, żeby było się czym dzielić" ${ }^{\prime 2}$. Wiedza ekspercka dotyczy w tym przypadku przede wszystkim pragmatyki życiowej. Mądrość według P. Baltesa składa się z pięciu komponentów:

${ }^{15}$ A. Kozerska, Wybrane psychologiczne koncepcje mądrości z perspektywy badań nad uczeniem się w późnej dorostości, Zeszyty Naukowe Wyższej Szkoły Humanitas. Pedagogika, 2017, 10, s. 126.

${ }_{16}$ S. Steuden, P. Brudek, Ł. Florczyk, Mądrość jako efekt pozytywnego starzenia się, s. 73-87.

$17 \mathrm{Na}$ ten temat piszę szerzej w tekście K. Kuryś-Szyncel, Międzygeneracyjny mentoring, [w:] Psychologia starzenia się i strategie dobrego życia, red. A. Błachnio, K. Kuryś-Szyncel, E. Martynowicz, A. Molesztak, Warszawa 2017 s. 137-159.

${ }_{18}$ Por.: K. Kuryś-Szyncel, „Bo inność drażni jednakowość”. Konfrontacja z zadaniami rozwojowymi dorostości jako źródło konfliktu, [w:] Sytuacje trudne w perspektywie jednostkowej i społecznej, red. H. Karasińska, E. Silecka-Marek, Poznań 2016, s. 52-70.

${ }_{19}$ Mowa tutaj o tzw. krytycznych wydarzeniach życiowych, czyli nagłych, niespodziewanych, niewpisanych w bieg życia zdarzeniach życiowych najczęściej o charakterze przełomowym. Na ten temat zob. np. K. Kuryś, Urodzenie pierwszego dziecka jako wydarzenie krytyczne w życiu kobiet i mężczyzn, Kraków 2010.

${ }^{20}$ P.B. Baltes, J. Glück, U. Kunzmann, Mądrość. Jej struktura i funkcja, s. 117-146.

${ }^{21}$ Tamże, s. 117-146, cyt. za P.K. Oleś, Psychologia człowieka dorosłego, Warszawa 2011, s. 261. 
1. Bogata i trafna wiedza o ludzkiej naturze i biegu życia.

2. Bogata wiedza proceduralna dotycząca sposobów postępowania wobec problemów życiowych.

3. Kontekstualizm biegu życia, czyli świadomość i zrozumienie wielu kontekstów życia oraz ich zmienności w biegu życia człowieka.

4. Relatywizm wartości i tolerancja, czyli uznawanie różnic indywidualnych, społecznych i kulturowych co do wartości i priorytetów życiowych.

5. Wiedza o utrzymaniu niepewności, włączając w to ograniczenie własnej wiedzy²2.

Wymienione komponenty wiążą się z tak zwanym doświadczeniem życiowym. Można bowiem przypuszczać, że ekspertem w dziedzinie pragmatyki życia będzie ten, kto nie tylko „wiele w życiu przeżył”, ale także w sposób twórczy (kreatywny) podjął refleksję nad własnym postępowaniem, dokonał bilansu zysków i strat oraz zintegrował zarówno trudne wydarzenia życiowe (porażki) jak i sukcesy. Mądrość życiowa może być zatem pozytywnym skutkiem radzenia sobie z krytycznymi wydarzeniami życiowymi i dowodem na dokonanie korzystnej tranzycji ${ }^{23}$.

Mądrość, szczególnie mądrość życiowa, wymaga postawy aktywnej i gotowości do uczenia się biograficznego. Nie jest ani dyspozycją wrodzoną ani też kompetencją nabywaną w toku socjalizacji. Czynnikiem sprzyjającym nabywaniu mądrości jest motywacja do uczenia się z doświadczeń życiowych oraz gotowość do sprawdzania tej wiedzy w życiu. Poza tym konieczna jest swoista integracja intelektu i charakteru, rozumiana jako

synteza zdolności intelektualnych, dostępność mentorów, opanowanie krytycznych doświadczeń życiowych, otwartość na nowe doświadczenia i wartości odnoszące się do osobowego wzrostu i rozwoju oraz życzliwość i tolerancja ${ }^{24}$.

Mądrość życiowa jest zatem nierozerwalnie związana z otwartością człowieka na podejmowanie refleksji nad własną biografią. Okazją do uczenia się biograficznego i jednocześnie zdobywania coraz większej biegłości w wiedzy na temat własnego życia stanowią tak zwane epizody wspólnego doświadczenia biograficznego, które mogą odegrać znaczącą rolę w procesie nabywania mądrości życiowej.

\section{Epizody wspólnego zaangażowania biograficznego - nowa perspektywa uczenia się w dorosłości}

Termin epizody wspólnego zaangażowania biograficznego (EWZB) jest autorską kompilacją propozycji Rudolpha Schaffera dotyczącej epizodów

${ }^{22}$ U. Kunzmann, P.B. Baltes, The psychology of wisdom: Theoretical and empirical challenges, [w:] A handbook of wisdom, s. 117, cyt. za: P.K. Oleś, Psychologia człowieka dorosłego, s. 262.

${ }^{23} \mathrm{Na}$ ten temat piszę m.in. w książce K. Kuryś, Urodzenie pierwszego dziecka.

${ }^{24}$ P.K. Oleś, Psychologia człowieka dorostego, s. 263. 
wspólnego zaangażowania ${ }^{25}$, które odnoszą się przede wszystkim do edukacyjnej relacji dorosły-dziecko z wiedzą na temat uczenia się biograficznego $^{26}$. Zgodnie z propozycją Schaffera, epizody wspólnego zaangażowania są sytuacjami o charakterze interakcyjnym. Za sprawą aktywnego zaangażowania dorosłego, służą one głównie poszerzaniu i wzbogacaniu repertuaru zachowań dziecka przez to, że pomagają mu opanować pewien nowy problem i tą drogą przenoszą je na wyższy poziom kompetencji w radzeniu sobie z wymaganiami otoczenia ${ }^{27}$. Zdaniem tego badacza, epizod jest swoistym spotkaniem $\mathrm{i}$ „,aby takie spotkanie miało sens, uczestnicy na początku muszą dojść do zgody co do tematu, którym będą się wspólnie zajmować"28. Mechanizmem odpowiedzialnym za zmianę (czyli za poszerzenie i wzbogacenie repertuaru zachowań) jest „konflikt centracji doświadczanych przez podmiot $\mathrm{w}$ trakcie interakcji" ${ }^{29}$. Uczestnicy interakcji natrafiają na odmienne punkty widzenia (każdy partner interakcji może mieć np. inny pomysł na rozwiązanie problemu) i zostają zmuszeni do skoordynowania swojego punktu widzenia z punktem widzenia partnera. Przejście na wyższy poziom kompetencji nie jest jednak możliwe tylko poprzez bierne "przyglądanie się" prezentacjom różnic, ale wymaga aktywnego uczestnictwa (zaangażowania) „w proces przeciwstawiania się poszczególnym opiniom i w proces rozumowania z użyciem opinii innych osób" ${ }^{30}$. Uczestnicy interakcji doświadczają w ten sposób konfrontacyjnego konfliktu społeczno-poznawczego ${ }^{31}$ skutecznego tym bardziej, im mocniej proponowane podczas interakcji zachowania przekraczają ich strefę aktualnego rozwoju uczestników ${ }^{32}$.

W opisie epizodów wspólnego zaangażowania istotne są zatem dwie kategorie: samo spotkanie jako interakcja oraz temat tego spotkania, a mecha-

${ }^{25}$ H.R. Schaffer, Epizody wspólnego zaangażowania jako kontekst rozwoju poznawczego, [w:] Dziecko w świecie ludzi i przedmiotów, red. A. Brzezińska, G. Lutomski, Poznań 1994, s. 150-188.

${ }^{26}$ O. Czerniawska, Szkice z andragogiki i gerontologii, Łódź 2007; E. Dubas, „Uczenie się z biografii Innych" - wprowadzenie, [w:] Uczenie się z biografii Innych, red. E. Dubas, W. Świtalski, Łódź 2011, s. 5-11.

${ }^{27}$ H.R. Schaffer, Epizody wspólnego zaangażowania jako kontekst rozwoju poznawczego, s. 150188.

${ }^{28}$ Tamże, s. 153.

29 A.N. Perret-Clermont, Social Interaction and Cognitive Development in Children, Academic; cyt. za: H.R. Schaffer, Epizody wspólnego zaangażowania jako kontekst rozwoju poznawczego, s. 178. 179.

${ }^{30}$ H.R. Schaffer, Epizody wspólnego zaangażowania jako kontekst rozwoju poznawczego, s. 178-

${ }^{31}$ Patrz: tamże.

32 Strefa aktualnego rozwoju i strefa najbliższego rozwoju to pojęcia wprowadzone przez Lwa Wygotskiego, patrz: L.S. Wygotski, Narzędzie i znak w rozwoju dziecka, Warszawa 2006. Strefa aktualnego rozwoju obejmuje te zadania, z którymi osoba radzi sobie samodzielnie. W strefie najbliższego rozwoju mieszczą się natomiast zadania, których nie potrafi ona wykonać samodzielnie, ale przy wsparciu innego, bardziej doświadczonego (dojrzałego) jest w stanie sobie z nimi poradzić, dzięki czemu zdobywa nową wiedzę poznawczą. 
nizmem, który przyczynia się do efektywnego oddziaływania edukacyjnego jest, opisany powyżej, konflikt centracji.

Podstawą wzajemnego uczenia się dziecka od dorosłego i dorosłego od dziecka podczas epizodu wspólnego zaangażowania jest naśladownictwo dziecko odwzorowuje zachowanie dorosłego, a dorosły odgrywa (wchodzi w rolę) zachowanie dziecka, by stać się bardziej podobnym, bliskim, synchronicznym (dostosowuje postawę ciała do wzrostu dziecka, mówi łagodnym ciepłym tonem głosu, a nawet przejmuje słownictwo dziecka). Stwarza tym samym przestrzeń wspólnego zaangażowania i wskazuje drogi dojścia do rozwiązań przekraczających strefę aktualnego rozwoju dziecka. Naturalna dziecięca ciekawość świata oraz gotowość poznawcza są z całą pewnością ułatwieniem dla dorosłego. Można powiedzieć, że cokolwiek nowego zaproponuje dorosły, dziecko (o ile czuje się bezpiecznie w relacji z tymże dorosłym) będzie tym zainteresowane i ufne.

Podczas uczenia się dorosłego od dorosłego nie możemy już liczyć na spontaniczność i bezwarunkowe zaufanie. Dorosły jako uczeń oczekuje, ma wymagania, sprawdza wiarygodność edukatora. Knud Illeris, charakteryzując różnice między „ufnym i «nieocenzurowanym» uczeniem się dzieci a uczeniem się dorosłych, które jest przede wszystkim wybiórcze i samosterowne" ${ }^{\prime \prime}$, stwierdza, że:

jeżeli dorośli mają zmieniać i udoskonalać swoje możliwości w zakresie uczenia się, to wszelkie zewnętrzne działania muszą być dla nich przekonujące. Na przykład, dorośli muszą zaakceptować proponowany im obszar uczenia się i widzieć związek między realizowanym programem edukacyjnym a pytaniami stawianymi sobie $\mathrm{w}$ nawiązaniu do osobistych doświadczeń biograficznych ${ }^{34}$.

W procesie uczenia się dorosłych, procesie, który ma przyczynić się do ich dalszego rozwoju (poznawczego, społecznego i emocjonalnego, ale także do tzw. rozwoju osobistego), istotne znaczenie mają dwie zaangażowane strony oddziaływań: edukator ze swoją adekwatną (atrakcyjną) ofertą oraz zainteresowany (ciekawy, otwarty na nowe) uczeń/uczący się. Istotne jest zatem, by edukator i jego dorosły uczeń uzgodnili wspólny obszar zaangażowania (temat) i zgodzili się co to tego, że ich wzajemna relacja ma na celu wywołanie konfliktu centracji.

Zaproponowany przez Schaffera model można odnieść do każdej relacji spotkania $\mathrm{z}$ bardziej doświadczonym (biegłym w danej dziedzinie życia) znaczącym Innym ${ }^{35}$, rozumianym, za Elżbietą Dubas, nie jako każdy Inny, ale

${ }^{33}$ K. Illeris, O specyfice uczenia się ludzi dorostych, Teraźniejszość - Człowiek - Edukacja: kwartalnik myśli społeczno-pedagogicznej, 2009, 1(45), s. 87-88.

${ }^{34}$ Tamże.

${ }^{35}$ Stosuję pisownię wielką literą zaproponowaną przez Elżbietę Dubas. 
Inny jako Bliźni - bliski, drogi towarzysz, przyjaciel. To rozumienie określa pozytywny stosunek do Innego. Inny jest wartością, wyznacza otwarcie się na Innego, chęć poznania Innego, chęć zbliżenia się do Innego (...). To rozumienie oznacza współbycie ${ }^{36}$.

Dostrzeżenie Inności wymaga rewizji własnych doświadczeń biograficznych ${ }^{37}$. Relacja z Innym może zatem zyskać wymiar edukacyjny oparty na regułach uczenia się biograficznego ${ }^{38}$ i może stanowić naturalną zachętę do konfliktu centracji, gdyż Inność zakłada różnicę.

Przyjrzyjmy się zatem bliżej warunkom niezbędnym do tego, aby relacja społeczna o charakterze edukacyjnym (edukator-uczeń) pomiędzy dwiema osobami dorosłymi zyskała status epizodu wspólnego zaangażowania biograficznego.

Epizod wspólnego zaangażowania biograficznego (EWZB) to sytuacja, w której edukator jest aktywnie zaangażowany w poszerzanie repertuaru zachowań ucznia/studenta, pomagając mu opanować pewien nowy problem i tą drogą przenosi go na wyższy poziom kompetencji w radzeniu sobie z wymaganiami otoczenia. EWZB opisuje każdy kontakt między dwiema (lub więcej) osobami, podczas którego uczestnicy wspólnie zwracają uwagę na jakiś zewnętrzny bądź wewnętrzny temat i wspólnie względem niego działają. Takim tematem może być przedmiot, zdarzenie lub inna cecha otoczenia, a także opowieść (auto)biograficzna ${ }^{39}$.

Temat zewnętrzny w EWZB to każda narracja pochodząca spoza kontekstu interakcji - może się ona odnosić na przykład do dzieł sztuki (filmu, obrazu, książki), po który sięga edukator/mentor/coach w procesie uczenia. Tematem zewnętrznym mogą być (i najczęściej są) tak zwane wielkie narracje, czyli, jak za Paulem Ricoeur'em pisze Elżbieta Dryll, teksty wzorcowe.

Należą one do kanonu opowiadań powszechnie znanych w danej kulturze, w wielu kulturach sobie współczesnych, lub także w innych, które były lub będą. Niektóre mają charakter sakralny, dzięki czemu zachowują swą niezmienność i ważność przez pokolenia. Są starannie przechowywane, nie ulegają modyfikacji, ani nie są wrażliwe na aktualne trendy intelektualne ${ }^{40}$.

36 E. Dubas, "Uczenie się z biografii Innych”, s. 6.

37 K. Kuryś-Szyncel, "Bo inność drażni jednakowość", s. 52-70.

38 Patrz m.in.: P. Alheit, Teoria biografii jako fundament pojęciowy uczenia się przez całe życie, przekł. A. Nizińska, Teraźniejszość - Człowiek - Edukacja: kwartalnik myśli społeczno-pedagogicznej, 2015, 4(72), s. 23-35; tenże, Podejście biograficzne do całożyciowego uczenia się, przekł. P. Poniatowska, Teraźniejszość - Człowiek - Edukacja: kwartalnik myśli społeczno-pedagogicznej, 2011, 3(55), s. 7-21.

39 Por.: H.R. Schaffer, Epizody wspólnego zaangażowania jako kontekst rozwoju poznawczego, S. 178-179.

40 E. Dryll, Narracje rodzinne, [w:] Psychologia rodziny, red. I. Janicka, H. Liberska, Warszawa 2014, s. 73-93. 
Tematem zewnętrznym w EWZB mogą być także biografie innych osób, w jakimś sensie znaczących dla członków wspólnoty uczącej się (np. poznawanie biografii znanych matematyków przez grupę studentów matematyki). Wprowadzenie tematu zewnętrznego do interakcji daje szansę na uruchomienie procesu uczenia się z biografii Innych. Jak pisze Elżbieta Dubas:

Uczenie się z biografii Innego - to uczenie się z przypominanych doświadczeń (a więc pośrednio), zawartych w pamięci biograficznej, w wyniku refleksji nad biografią Innego. Biografia ta może być opowiadana, czytana, oglądana itp., zawarta w pamiętnikach, autobiografiach, dziennikarskich wywiadach biograficznych, w informacjach biograficznych publikowanych $\mathrm{w}$ mediach, $\mathrm{w}$ tym $\mathrm{w}$ artykułach prasowych, audycjach radiowych, reportażach telewizyjnych, filmach dokumentalnych i fabularyzowanych itp. Biografia zawiera doświadczenia pamiętane, wspominane, możliwe do przypomnienia. Wiąże się z refleksją nad doświadczeniami, które miały miejsce, dzieją się aktualnie, a także mogą się wydarzyć w przyszłości. Uczenie się z biografii Innego wymaga więc namysłu nad jego biografią i odnoszenia jego doświadczeń biograficznych do własnej samowiedzy i posiadanej wiedzy o świecie. Namysł nad biografią Innego wnosi nowe wartości w nasz sposób oglądu i rozumienia świata, a w następstwie $\mathrm{w}$ nasze zachowanie się-bycie $\mathrm{w}$ świecie ${ }^{41}$.

Podobnie Monika Adamska-Staronn ${ }^{42}$, analizując spotkanie jako kategorię pedagogiczną, także zwraca uwagę na spotkanie z Innym i również traktuje je bardzo szeroko. Takie spotkanie może bowiem odnosić się zarówno do spotkania personalnego (osoby z osobą), jak i spotkania "przedmiotowego" (np. osoby z tekstem kultury). Adamska-Staroń tak pisze:

Człowiek zanurzając się w przestrzeń relacji, zapytuje o rzeczywistość już w dialogicznej perspektywie, sam również może być zagadnięty przez inny byt - drugiego człowieka, czy też jego dzieło ${ }^{43}$.

Szczególnym warunkiem uczenia się z biografii Innego podczas EWZB jest wyzbycie się poczucia bycia ekspertem i znawcą życia. O takiej korzystnej relacji (także w kontekście edukacyjnym) mówi Anna Gulczyńska:

ograniczone możliwości poznania drugiego człowieka (wynikające zarówno z biologii, jak i z samej natury poznania, w tym języka), zrozumienia go, a tym bardziej wydania dopasowanych instrukcji, czy idealnych porad, nakładają na pomagających pewne ograniczenia, a także wymagają, aby pozbyli się oni ułudy władzy ${ }^{44}$.

41 E. Dubas, "Uczenie się z biografii Innych", s. 8.

${ }^{42}$ M. Adamska-Staroń, Spotkanie z Innym w perspektywie idei dialogu, Prace Naukowe Akademii im. Jana Długosza w Częstochowie. Pedagogika, 2014, 23, s. 95-101; taże, Spotkanie z wybranymi tekstami kultury popularnej. W stronę relacyjnego bycia w świecie, Studia Edukacyjne, 2018, 50, s. 332-397.

${ }^{43}$ M. Adamska-Staroń, Spotkanie z wybranymi tekstami kultury popularnej, s. 333.

44 A. Gulczyńska, Zmierzch interakcji instruktywnej. W stronię autonomii w dialogu rodzice nauczyciele, Studia Edukacyjne, 2019, 52, s. 274. 
Temat wewnętrzny natomiast stanowi autonarracja ( $w$ tym także narracja na temat współbycia) uczestników EWZB. Może nim być historia życia (ang. life story) lub opowieść tematyczna, na przykład o sposobach radzenia sobie $\mathrm{z}$ trudnościami. Tematem wewnętrznym są zatem tak zwane średnie narracje odnoszące się do życia wybranej wspólnoty (semantycznego systemu znaczeń), jak na przykład rodzina ${ }^{45}$ oraz małe narracje. Elżbieta Dryll tak charakteryzuje obydwa typy narracji:

Narracje średniego zasięgu dotyczą aktualnych problemów nurtujących życie społeczne. W tym zawierają się także tematy rodzinne - miłości, małżeństwa, rodzicielstwa, wychowania. Pozostają one pod wpływem dominujących trendów intelektualnych swoich czasów (...) Narracje "małe" to opowieści codzienne, które słyszy i tworzy każdy człowiek ${ }^{46}$.

Uczestnicy EWZB dzielą się między sobą osobistymi narracjami na tematy ważne i znaczące dla tworzonej przez nich w danym czasie wspólnoty. Przykładem może być początek cyklu rozwoju rodziny (tzw. faza preparentalna), kiedy partnerzy uwspólniają znaczenia poprzez uaktywnianie osobistych narracji. Źródłem tych narracji są osobiste (jednostkowe) doświadczenia życia $w$ rodzinie pochodzenia ${ }^{47}$. Opowiadanie o sobie, strukturyzowanie własnych doświadczeń stwarza niepowtarzalną szansę uczenia się z własnej biografii. O procesie tym E. Dubas tak pisze:

Uczenie się z własnej biografii to uczenie się z przypominanych własnych doświadczeń, zawartych we własnej pamięci biograficznej, w wyniku refleksji nad własną biografią (autobiografią). Może odbywać się sytuacji wywiadu biograficznego, jak i biograficznych zajęć edukacyjnych i terapeutycznych czy też indywidualnie prowadzonej refleksji autobiograficznej ${ }^{48}$.

Interakcje podczas epizodów wspólnego zaangażowania biograficznego (EWZB) dotyczą szerokiego zakresu tematów i dzięki temu mogą także stawać się źródłem kompetencji biograficznej, przez którą Zbigniew Pietrasiński rozumie umiejętność współtworzenia przez jednostkę własnego życia i rozwoju oraz wspomaganie rozwoju innych_w sposób coraz bardziej systemowy ${ }^{49}$.

${ }^{45} \mathrm{~W}$ tekście K. Kuryś, Tematyczne narracje autobiograficzne kobiet i mężczyzn wobec tworzenia biografii rodzinnej, [w:] Psychologia małych i wielkich narracji, red. M. Straś-Romanowska, B. Bartosz, M. Żurko, Warszawa 2010, s. 131-150 nazywam narracje rodzinne quasi-wielkimi narracjami.

${ }^{46}$ E. Dryll, Narracje rodzinne, [w:] Psychologia rodziny, red. I. Janicka, H. Liberska, Warszawa 2014, s. 73-93.

${ }^{47} \mathrm{Na}$ ten temat patrz np. K. Kuryś-Szyncel, Biograficzne uczenie się w perspektywie rodzinnej - systemowe transmisje, [w:] Rodzinne (re)konstrukcje i transmisje w perspektywie biograficznej, red. K. Kuryś-Szyncel, Poznań 2017, s. 55-68.

48 E. Dubas, "Uczenie się z biografii Innych", s. 7.

49 Z. Pietrasiński, Rozwój człowieka dorostego, Warszawa 1990, s. 136-144. 
Ponieważ praktyka życiowa człowieka dorosłego jest wypadkową wielu sytuacji i dążeń, istnieje małe prawdopodobieństwo, by bez specjalnych starań zapewniała ona jednostce rozwój optymalny z punktu widzenia jej życia jako całości. Instrumentalne traktowanie przez dorosłych własnego rozwoju sprzyja jego dysharmonii, brzemiennej w liczne następstwa, dyktuje bowiem zwykle strategię koncentracji na zadaniach najbardziej oczywistych lub natarczywych (np. dokształcanie dla awansu i ucieczka przed psychoterapią pomimo fatalnego oddziaływania na własne dzieci). Dlatego wyłania się istotne pytanie: jakie właściwości już nie otoczenia i wykonywanej pracy, lecz samej jednostki są potrzebne do optymalizacji jej osobistego rozwoju? Jednym z przejawów rozwoju (...) jest to, że człowiek dorosły staje się coraz lepiej znającym się na rzeczy współtwórcą własnej drogi życiowej i własnego rozwoju. Innymi słowy zyskuje coraz większą kompetencję biograficzną ${ }^{50}$.

Pietrasiński podkreśla ponadto, że w dorosłości nie tyle chodzi o kierowanie rozwojem (nie dysponujemy bowiem jednoznacznie określonymi ramami rozwojowymi, jak w przypadku dzieciństwa - np. normy centylowe $\mathrm{w}$ odniesieniu do rozwoju biologicznego), co o kierowanie życiem ${ }^{51}$. Współczesna wielość i swoista wolność $\mathrm{w}$ dokonywaniu wyborów własnej ścieżki biograficznej otwiera przed jednostką nieskończone możliwości, ale jednocześnie może wzbudzać niepewność, lęk i paradoksalnie hamować poszukiwanie niezależnych, autonomicznych rozwiązań biograficznych ${ }^{52}$.

Zatem, EWZB także mają charakter socjalizująco-personalizujący. Zapewniają przestrzeń do uczenia się zachowań oczekiwanych i aprobowanych społecznie. Umożliwiają uczenie się z biografii Innych, z założenia bardziej biegłych i doświadczonych zarówno w praktyce życia codziennego, jak i praktyce życia zawodowego (np. związanego z wybraną profesją). Podczas EWZB zachodzi także transfer doświadczeń generacyjnych (intergeneracyjnych), który stanowi podstawę międzypokoleniowego mentoring $\mathrm{u}^{53}$.

EWZB stwarzają również szansę na uruchomienie procesów tożsamościowych i zdobywanie tak zwanej mądrości życiowej. Uczenie się w dorosłości to przede wszystkim uczenie się biograficzne, egzystencjalne, a nie czysto poznawcze poszerzanie repertuaru wiedzy fachowej (dziedzinowej). Uczenie się w dorosłości to poszerzanie wiedzy o życiu. Dorosły dzięki wypracowanym wcześniej schematom poznawczym może odszukać dane i nie potrzebuje, co więcej, nie chce opanowywać ich pamięciowo (stąd często niechęć dorosłych do uczenia się tak zwanej twardej wiedzy-teorii, np. podczas studiów wyższych). Dorosły chce wiedzieć, do czego przekazywane informacje mogą mu się przydać, chce poznać okoliczności, w których będzie mógł je zastosować.

50 Tamże, s. 137.

51 Tamże, s. 138.

52 Na temat konfliktu wynikającego z realizacji zadań życiowych i rozwojowych piszę szerzej w tekście: K. Kuryś-Szyncel, „Bo inność drażni jednakowośćc, s. 52-70.

53 Na ten temat piszę szerzej w: K. Kuryś-Szyncel, Międzygeneracyjny mentoring, s. 137-159. 
Uczenie się $\mathrm{w}$ dorosłości jest zatem sensowne i wybiórcze, dostosowane do własnych aktywności, zainteresowań, do tak zwanej praktyki życia.

\section{Epizody wspólnego zaangażowania biograficznego drogą do mądrości życiowej? - próba podsumowania}

„Sposobów nabywania mądrości jest wiele, nie ma jednej recepty na mądrość, raczej jest to nieprzebrana wielość indywidualnych ścieżek" ${ }^{\prime \prime 4}$. Robert Sternberg uważa, że mądrość nie polega na mądrym myśleniu, ale na mądrym postępowaniu.

Kierowanie się mądrością w życiu umacnia jego jakość, sprzyja poczuciu integracji, łączy się z pogłębioną refleksyjnością, roztropnością, większą odpowiedzialnością, działaniem na rzecz wspólnego dobra, ale niekiedy wiąże się z cierpieniem, zamartwianiem się, niepokojem czy koniecznością z rezygnacji osobistych pragnień i dążeń55

Epizody wspólnego zaangażowania biograficznego mogą pojawiać się jako planowana, celowa metodyka (sposób pracy) w procesie edukacji osób dorosłych, które bądź już pracują, bądź też zamierzają pracować z innymi ludźmi w szeroko rozumianym obszarze poradnictwa, wsparcia, ale także na przykład edukacji na poziomie akademickim. EWZB stwarzają bowiem okazję do uczenia się biograficznego, a co za tym idzie pogłębiają motywację do podejmowania refleksji nad życiem własnych i Innych. Podczas EWZB dochodzi do wielu okoliczności (warunków), które mogą stanowić, w myśl propozycji P. Baltesa i jego współpracowników ${ }^{56}$, źródła (edukacyjne) mądrości.

Pierwsze źródło to doświadczanie okoliczności sprzyjających rozwojowi mądrości. Wprowadzenie do EWZB tematu wewnętrznego w postaci opowieści autobiograficznej w grupie osób, które łączy wspólny kontekst życiowy, na przykład wiek, wykształcenie, rodzicielstwo, stwarza okazję do dzielenia się sposobami radzenia sobie z trudnościami, wskazywania źródeł sukcesów w określonej pragmatyce życia, a przez to stanowi cenne źródło wiedzy eksperckiej - jako podstawy mądrości życiowej. Podobnie, jeśli podczas EWZB pojawia się znacząca biografia Innego. Sprzyja ona nabywaniu wiedzy zarówno o sposobach i strategiach "dobrego życia”, jak też jako egzemplifikacja zachowań i działań destrukcyjnie działających na bieg życia człowieka (mowa

\footnotetext{
${ }^{54}$ P.K. Oleś, Psychologia człowieka dorosłego, s. 263.

${ }_{55}$ R.J. Sternberg, Wisdom, Intelligence and Creativity Sythesized, New York 2003, s. 152-173, cyt. za: S. Steuden, P. Brudek, Ł. Florczyk, Mądrość jako efekt pozytywnego starzenia się. Perspektywa psychologiczna, s. 78.

${ }^{56}$ P.B. Baltes, J. Glück, U. Kunzmann, Mądrość. Jej struktura i funkcja, s. 126.
} 
tu o uczeniu się z cudzych doświadczeń). Kolejnym źródłem wskazywanym przez P. Baltesa są czynniki związane ze znawstwem. EWZB dostarczają niezliczonych treści (narracji) na temat doświadczeń życiowych. W warunkach ustrukturyzowanych (np. w procesie edukacji akademickiej) dają także możliwość bycia w relacji z mentorami, „terminowania u mistrza” (np. promotora). Po stronie uczącego się dorosłego może budzić się motywacja wynikająca z zainteresowania różnorodnością i dążenie do doskonałości. Ważne jest, by edukator (np. wykładowca akademicki) był otwarty zarówno na dzielenie się własną biografią, jak i poznawanie biografii swoich dorosłych uczniów. Ujawnianie $\mathrm{w}$ takiej relacji konfliktu centracji polega przede wszystkim na różnicowaniu, które dzięki refleksyjnemu edukatorowi staje się wyzwaniem i motywuje do dalszych poszukiwań (także w obszarze doskonalenia własnej osobowości, autokreacji i rozwoju osobistego). Paul Baltes mówi ponadto, że istotne źródło mądrości życiowej stanowi także sama osoba (przede wszystkim jej konstrukcja poznawcza), której zależy na zdobyciu tejże mądrości. Wskazuje się tutaj na kreatywność i elastyczność poznawczą. EWZB stanowią niepowtarzalną okazję do „ćwiczenia się" w niekonwencjonalnym rozwiązywaniu problemów, poszukiwaniu nowych, nieznanych dotąd rozwiązań (np. poprzez czerpanie z doświadczeń biograficznych Innego). Edukacyjnymi przykładami takiego poznawczo-emocjonalnego "pobudzenia" są wszelkie aktywne formy pracy wykorzystujące konwencję gry (np. mechanika oparta na rzucie kostką), która w swej warstwie fabularnej oparta jest na założeniach psychologii biegu życia (life span psychology) oraz uczenia się biograficznego i zawiera treści pochodzące od samych uczestników gry (autobiografie), jak również narracje pochodzące z zewnątrz (dostarczone przez prowadzącego) ${ }^{57}$.

Na zakończenie warto podkreślić, że

można mądrzeć, nawet nie stawiając sobie takiego celu. Przyrost wiedzy i sprawności bywa niezamierzonym efektem ubocznym innych działań (...) Trudno jednak wątpić, że wyraźne postawienie sobie celu przybliża doń jeszcze skuteczniej ${ }^{58}$.

Opisane w niniejszym opracowaniu epizody wspólnego zaangażowania biograficznego (EWZB) poprzez uruchomienie konfliktu centracji zdają się stanowić doskonałe okazje do uczenia się (także biograficznego) w dorosłości i nabywania mądrości życiowej.

${ }^{57}$ Przykładem takiej innowacji dydaktycznej jest prowadzona przeze mnie w ramach zajęć „Projektowanie rozwiązań biograficznych”, dedykowanych studentom III roku pedagogiki opiekuńczo-wychowawczej na Wydziale Studiów Edukacyjnych UAM w Poznaniu, ",Gra (auto) biograficzna”. Szczegółowy opis mechaniki i fabuły został przedstawiony w artykule K. Kuryś, Grupowa interakcja autobiograficzna - znaczenie socjoterapeutyczne, [w:] Socjoterapia jako forma pomocy psychologiczno-pedagogicznej. Teoria i praktyka, red. B. Jankowiak, Poznań 2013, s. 229-241.

58 Z. Pietrasiński, Mądrość, czyli świetne wyposażenie umystu, s. 118. 


\section{BIBLIOGRAFIA}

Adamska-Staroń M., Spotkanie z Innym w perspektywie idei dialogu, Prace Naukowe Akademii im. Jana Długosza w Częstochowie. Pedagogika, 2014, 23.

Adamska-Staroń M., Spotkanie z wybranymi tekstami kultury popularnej. W stronę relacyjnego bycia w świecie, Studia Edukacyjne, 2018, 50.

Alheit P., Podejście biograficzne do całożyciowego uczenia się, przekł. P. Poniatowska, Teraźniejszość - Człowiek - Edukacja: kwartalnik myśli społeczno-pedagogicznej, 2011, 3(55).

Alheit P., Teoria biografii jako fundament pojęciowy uczenia się przez całe życie, przekł. A. Nizińska, Teraźniejszość - Człowiek - Edukacja: kwartalnik myśli społeczno-pedagogicznej, 2015, 4(72).

Baltes P.B., Glück J., Kunzmann U., Mądrość. Jej struktura i funkcja w kierowaniu pomyślnym rozwojem w okresie całego życia, [w:] Psychologia pozytywna. Nauka o szczęściu, zdrowiu, sile i cnotach człowieka, red. J. Czapiński, Wydawnictwo Naukowe PWN, Warszawa 2004.

Bassett C., Emergent wisdom: Living a life in widening circles, ReVison, 2005, 27.

Błachnio A., Autor siebie w trzeciej fali cywilizacyjnej, Wydawnictwo UKW, Bydgoszcz 2006.

Błachnio A., Człowiek autorski w erze globalizacji, Wydawnictwo UKW, Bydgoszcz 2011.

Czerniawska O., Szkice z andragogiki i gerontologii, Wydawnictwo WSHE, Łódź 2007.

Dryll E., Narracje rodzinne, [w:] Psychologia rodziny, red. I. Janicka, H. Liberska, Wydawnictwo Naukowe PWN, Warszawa 2014.

Dubas E., "Uczenie się z biografii Innych" - wprowadzenie, [w:] Uczenie się z biografii Innych, red. E. Dubas, W. Świtalski, Wydawnictwo UŁ, Łódź 2011.

Gulczyńska A., Zmierzch interakcji instruktywnej. W stronię autonomii w dialogu rodzice nauczyciele, Studia Edukacyjne, 2019, 52.

Illeris, K., O specyfice uczenia się ludzi dorostych, Teraźniejszość - Człowiek - Edukacja: kwartalnik myśli społeczno-pedagogicznej, 2009, 1(45).

Kabat-Zinn J., Mindfulness-Based Interventions in Context: Past, Present, and Future, Clinical Psychology: Science and Practice, 2003, 10.

Kozerska A., Wybrane psychologiczne koncepcje madrości z perspektywy badań nad uczeniem się w późnej dorosłości, Zeszyty Naukowe Wyższej Szkoły Humanitas. Pedagogika, $2017,10$.

Kunzmann U., Baltes P.B., The psychology of wisdom: Theoretical and empirical challenges, [w:] A handbook of wisdom. Psychological perspectives, red. R.J. Sternberg, J. Jordan, Cambrige University Press, Cambrige 2005.

Kuryś K., Tematyczne narracje autobiograficzne kobiet i mężczyzn wobec tworzenia biografii rodzinnej, [w:] Psychologia małych i wielkich narracji, red. M. Straś-Romanowska, B. Bartosz, M. Żurko, ENETEIA Wydawnictwo Szkolenia, Warszawa 2010.

Kuryś K., Urodzenie pierwszego dziecka jako wydarzenie krytyczne w życiu kobiet i mężczyzn, Oficyna Wydawnicza Impuls, Kraków 2010.

Kuryś K., Grupowa interakcja autobiograficzna - znaczenie socjoterapeutyczne, [w:] Socjoterapia jako forma pomocy psychologiczno-pedagogicznej. Teoria i praktyka, red. B. Jankowiak, Wydawnictwo Naukowe UAM, Poznań 2013.

Kuryś-Szyncel K., "Bo inność drażni jednakowość”. Konfrontacja z zadaniami rozwojowymi dorostości jako źródto konfliktu, [w:] Sytuacje trudne w perspektywie jednostkowej i społecznej, red. H. Karasińska, E. Silecka-Marek, Wydawnictwo Naukowe UAM, Poznań 2016.

Kuryś-Szyncel K., Biograficzne uczenie się w perspektywie rodzinnej - systemowe transmisje, [w:] Rodzinne (re)konstrukcje i transmisje w perspektywie biograficznej, red. K. Kuryś-Szyncel, Wydawnictwo Naukowe UAM, Poznań 2017. 
Kuryś-Szyncel K., Międzygeneracyjny mentoring, [w:] A. Błachnio, K. Kuryś-Szyncel, E. Martynowicz, A. Molesztak, Psychologia starzenia się i strategie dobrego życia, Wydawnictwo Difin, Warszawa, 2017.

Laubovie-Vief G., Wisdom as integrated throught: historical and developmental perspective, [w:] Wisdom: It's nature, origins, and development, red. R.J. Sternberg, Oxford University Press, New York 1990.

McAdams D.P., de St. Aubin E., Logan R.L., Generativity among young, midlife, and older adults, Psychology and Aging, 1993, 8.

Muszyński M., Teoria uczenia się egzystencjalnego Petera Jarvisa, Edukacja Dorosłych, 2013, 1.

Obuchowski K., Człowiek intencjonalny, czyli o tym jak być soba, Dom Wydawniczy Rebis, Poznań 2000.

Obuchowski K., The subjects' revolution, WSHE, Łódź 2005.

Oleś P.K., Psychologia człowieka dorosłego, Wydawnictwo Naukowe PWN, Warszawa 2011.

Ożarowski W., Ustalenie przydatności Popperowskiej zasady falsyfikacji do oceny koncepcji osobowości autorskiej, Horyzonty Psychologii, 2011, 1(1).

Perret-Clermont A.N., Social Interaction and Cognitive Development in Children, Academic Press, London 1980.

Pietrasiński Z., Rozwój człowieka dorosłego, Państwowe Wydawnictwo „Wiedza Powszechna", Warszawa 1990.

Pietrasiński, Z., Mądrość, czyli świetne wyposażenie umystu, Wydawnictwo Naukowe Scholar, Warszawa 2001.

Pietrasiński Z., Ekspansja pięknych umystów. Nowy renesans i ożywcza autokreacja, Wydawnictwo CIS, Warszawa 2008.

Schaffer H.R., Epizody wspólnego zaangażowania jako kontekst rozwoju poznawczego, [w:] Dziecko w świecie ludzi i przedmiotów, red. A. Brzezińska, G. Lutomski, Zysk i S-ka Wydawnictwo, Poznań 1994.

Staudinger U.M., Dörner J., Mickler C., Wisdom and personality, [w:] A handbook of wisdom. Psychological perspective, red. R.J. Sternberg, J. Jordan, Cambrige University Press, Cambrige 2005.

Steuden S., Brudek P., Florczyk Ł., Mądrość jako efekt pozytywnego starzenia się. Perspektywa psychologiczna, Forum Teologiczne, 2016, XVII.

Wygotski L.S., Narzędzie i znak w rozwoju dziecka, PWN, Warszawa 2006. 